\title{
Sheep and Goat Production, Challenges and Opportunities in Southern Ethiopia
}

\author{
Fikiru Getachew \\ Salale University, College of Agriculture and Natural Resource
}

\begin{abstract}
The study was conducted in Gedeb, Bule, Amaro, Gelana, Abaya and Dilla Zuria of southern Ethiopia to identify and describe Sheep and Goat production systems, production potentials and challenges. After a pilot survey, study districts were stratified based on agroecology and their potential. From each stratum, six districts were selected randomly and three kebeles were selected from each district; finally 180 households participated in data collections. The overall mixed farming system was dominant and the average landholding per household was more than 4 hectares; the mean landholding per household in Gelana and Abaya districts was significantly higher $(\mathrm{P}<0.05)$ than those of other districts. Sheep production was dominant in Bule (33.3\%) followed by Gedeb (30\%), while Goats were slightly dominant in Amaro and Gelana, overall mean was significant $(\mathrm{P}<0.05)$ across the districts and breed. The number of the animal was significantly different in all districts. Almost all respondents were kept small ruminant for income generation. Grazing of natural pasture and crop residue were common in Bule and Gedeb, while communal land grazing and browsing were common for Abaya and Gelana. Overall most of the respondents were kept their animal adjacent to their family house (37.8\%) followed by a separate room (27.8\%) and living with family (24.4\%). Lack of extension and credit support (21.7\%) was a major problem across the district followed by disease, parasite, Lack of input and technologies and market problems (17.2\%). Conducive environment, animal productivity and human population growth were major opportunities of small ruminant production in the study area. All respondents were responded small scale enterprises were not established. This study concludes that even if the environment of study areas were conducive for production of small ruminants, the production system is still backyard and there are no small scale enterprises engaged in small ruminant production, thus, extension service and credit should be facilitated and establishment of small scale on small ruminant production must be established in study districts.
\end{abstract}

Keywords: Goat, Sheep, Southern Ethiopia.

DOI: $10.7176 / \mathrm{JBAH} / 10-19-03$

Publication date:October $31^{\text {st }} 2020$

\section{INTRODUCTION}

Ethiopia has 1.13 million square $\mathrm{km}$ of land with suitable climatic conditions for crop and livestock production (NBE, 2011). The socio-economic significance of livestock is basic for most of the Ethiopian populations and widely recognized. The livestock sector is a source of draught power, nutritionally rich foods, fertilizer, industrial raw materials and foreign currency. The overall livestock sector contributes up to $25 \%$ of agricultural GDP and $11 \%$ of the total Ethiopian foreign exchange earnings (Behnke and Fitaweke, 2011).

The total livestock population in Ethiopia in 2012 was estimated at 54 million cattle, 25.5 million sheep and 24.1 million goats (CSA, 2013); this stock number is placing Ethiopia first in Africa and ninth in the world. However, the stock number is high the production and productivity are very small. Ethiopia's annual exports of cattle and sheep meat were valued at USD 79.13 million in 2012 (ECRA, 2012); this is due to several factors. For instant investments in modern animal husbandry are limited, inadequate veterinary services, feed shortages, poor infrastructure, insufficient financial services and low levels of technical inputs are well documented (Solomon et al., 2010).

Sheep and Goats are important livestock sub-sector and mainly kept for income generation of smallholder family, source of meat, skin, milk and wool throughout Ethiopia. Farmers considered small ruminants as a source of insurance and regulation of financial instabilities, source of risk mitigation, security, investment, saving and socio-economic and cultural functions due to high fertility, short generation interval, need low inputs and adaptability to a harsh environment. Thus, Sheep and goats provide about $12 \%$ of the total livestock products consumed and $48 \%$ of the family income generated at farm level and are accountable for about $25 \%$ of the domestic meat consumption and $58 \%$ of the national annual hide and skin production

However, little is known about the existing small ruminants' production systems and small scale enterprises engaged in small ruminant production, opportunities and challenges related to the small ruminant production in the study area. Understanding the existing production potentials and identifying of prevailing problems in the study area vital to devise appropriate development interventions to improve small ruminant production and small scale enterprises in the production of Sheep and Goats in the study area and the aim of the current study was

$\checkmark$ To characterize sheep and goat production system, major opportunities and constraints in southern Ethiopia. 


\section{MATERIALS AND METHODS}

\subsection{Study Area}

The study was conducted in Gedeo zone (Bule, Gedeb and Dilla Zuria districts), West Guji Zone (Abaya and Gelana districts) and Amaro special district of southern Ethiopia. The study areas were selected purposively based on the small ruminants' production potentials.

Gedeo zone is located at $90 \mathrm{~km}$ from Hawassa, the capital of South nation, nationalities and People region of Ethiopia. The zone has six districts namely, Bule, Gedeb, Dilla Zuria, Wonago, Yirgachaffe and Kochore with two urban (Dilla and Yirgachaffe). Geographically, the Zone is located North of Equator from 5 53' $\mathrm{N}$ to $6^{\circ} 27^{\prime} \mathrm{N}$ Latitude and from $38^{\circ} 8^{\prime}$ to $38^{\circ} 30^{\prime}$ East, Longitude. The altitude ranges from 1500 to $3000 \mathrm{~m}$ and has sub-humid tropical climate receives mean annual rainfall $1500 \mathrm{~mm}$. The rainfall pattern is bimodal, with short rain season between March and May accounting for 30\% of total rainfall and a long rainy season between July and October accounting for more than $60 \%$ of total rainfall. The Zone has three distinct agro ecologic Zone namely highland/Dega (30\%), mid highland/Woyina dega (67\%) and low land/Kola (3\%). The mean monthly temperature is $21.5^{\circ} \mathrm{C}(\mathrm{CSA}, 2007)$.

Amaro special district is found between $6^{\circ} 5^{\prime} \mathrm{N}$ Latitude and $38^{\circ} 2^{\prime} \mathrm{E}$ Longitude, bordered on the south by Burji special district, on the southwest by Konso special districts, on the west by Derashe special district, on the northwest by Gamo Gofa and Lake Chamo and on the north and east by West Guji zone of Oromia. The district constitutes highland/dega (30\%), mid-highland/woyina dega (38\%) and low-land/kola (32\%).

West Guji zone is located between $5^{\circ} 26^{\prime}$ and $5^{\circ} 52^{\prime}$ North Latitude and $37^{\circ} 56^{\prime}$ and $38^{\circ} 31^{\prime}$ East Longitude and an altitude between 1500 and 2400meters above sea level (West Guji Zone land and environment protection office, 2017). The zone is divided into three agro-ecology zones, namely the highland/dega (34\%), mid-highland/woyina dega $(55 \%)$ and low-land/kola (11\%). The rainfall pattern is bimodal, high rainfall between March and May as well as a relatively good amount from September to November.

\subsection{Sampling techniques}

After a pilot survey on the study area and identifying the possible areas, stratified sampling technique based on the agro-climatic zone of the study areas was used in selecting districts to cover those all districts with different altitudinal ranges, production systems and fair accessibility. From each district households were stratified into strata based on who had engaged in small ruminant production and not engaged and from those who had small ruminant households representative households were selected by simple random sampling techniques.

\subsection{Data Collection Techniques}

Before conducting the formal survey, group discussion was made with key informants such as elders and experts in the office of districts' livestock and fisheries to have an overview about small ruminants' production system in the study areas. To obtain primary data of the small ruminants' production system, a semi-structured questionnaire was developed and pre-tested. Finally, the formal survey was conducted by trained enumerators under close supervision and participation of the researchers.

Data were collected on the small ruminants' production systems of the areas, the small ruminant management practice, role of small ruminant production in household economic condition and small scale production enterprises, comparative feeding and nutrition and strategies for development, constraints and opportunities related to small ruminant production. Moreover, data concerning the traditional measures taken by small ruminant producing societies to solve problems associated with livestock husbandry practices.

\subsection{Data Analysis}

The quantitative and qualitative data were coded and analyzed using the means and frequency procedures of Statistical Package for Social Sciences (SPSS, 2013). Chi-square test was used to examine differences between levels of significance of different quantitative variables among districts and analysis of variance (ANOVA) using the general linear model procedure of SPSS. Least Significant Difference (LSD) test was made for mean separation when there was a significant difference among districts.

\section{RESULTS AND DISCUSSION}

\subsection{Household Characteristics}

The majority of small ruminant holders $(81 \%)$ were male-headed similarly across the study districts $(\mathrm{P}>0.05)$ table 1, this observation suggested that men take the lead to initiate and have the small ruminants, which is similar in most of the Ethiopian small ruminant producing areas (Dhaba et al., 2012). However, all household members, whether be it male or female, youth or adults were taking care of the animals; in keeping, providing them with a feed and ensuring their safety. Some respondents were responded as; the production of a small ruminant is suitable for female producers and most of the scholars argued as sheep and goat production is easier than keeping cattle.

About $31.8 \%$ of the producers fell between the age of 31 and 40 years, which indicates most of sheep and 
goat producers across the study districts, were in productive age. According to current finding, most (30\%) of respondents' family size was fail between 7 and 9 members per household; which was similar with results reported by Dhaba et al., (2012) and higher than the results reported by Belay et al., (2012).

Most of the respondents (45.6\%) were illiterate, followed by elementary (between 1and 4) school (40\%) and only $(2.2 \%)$ of them had a higher education certificate. Almost all $(63.3 \%)$ of farmers of Gelana district were significantly $(\mathrm{P}<0.05)$ have completed elementary school (1-4), followed by Dilla Zuria (46.7\%), Abaya (40\%), Gedeb (40\%) and Amaro (33.3\%); while almost all (80\%) of respondents from Bule were significantly illiterate. This implies most of the small ruminants' producers were keeping their animal in backyard system, had not entrepreneurship mind and difficult to give them some training to enhance their ability.

The mixed farming system was common $(32.8 \%)$, followed by the production of livestock (30\%), especially in Gedeb districts almost all (70\%) of respondents depended on livestock- crop production system, followed by respondents from Bule (33.3\%), Dilla zuria (33.3\%) and Amaro (30\%). The farmers of Abaya (56.7\%) were significantly participated in only a livestock production system, followed by Gelana (43.3\%).

Table 1: Households' Characteristics in Study Area (\%)

\begin{tabular}{|c|c|c|c|c|c|c|c|c|c|}
\hline \multirow{2}{*}{\multicolumn{2}{|c|}{ Descriptions }} & \multicolumn{6}{|c|}{ Study Districts } & \multirow[b]{2}{*}{ Total } & \multirow{2}{*}{$\begin{array}{l}\text { P- } \\
\text { value }\end{array}$} \\
\hline & & \multirow{2}{*}{\begin{tabular}{|l|} 
Gedeb \\
83.3
\end{tabular}} & \multirow{2}{*}{$\begin{array}{l}\text { Bule } \\
80.0\end{array}$} & \multirow{2}{*}{$\begin{array}{l}\text { Amaro } \\
80.0\end{array}$} & \multirow{2}{*}{$\begin{array}{l}\text { Gelana } \\
83.3\end{array}$} & \multirow{2}{*}{$\begin{array}{l}\text { Abaya } \\
80.0\end{array}$} & \multirow{2}{*}{$\begin{array}{l}\begin{array}{l}\text { Dilla } \\
\text { Zuria }\end{array} \\
80.0\end{array}$} & & \\
\hline Sex & Male & & & & & & & 81.0 & 0.99 \\
\hline & Female & 16.7 & 20.0 & 20.0 & 16.7 & 20.0 & 20.0 & 19.0 & \\
\hline \multirow[t]{6}{*}{ Age } & $\leq 20$ years & 16.7 & 13.3 & 10.0 & 10.0 & 6.7 & 13.8 & 11.7 & 0.01 \\
\hline & $21-30$ years & 26.7 & 16.7 & 10.0 & 0.0 & 16.7 & 27.6 & 16.2 & \\
\hline & $31-40$ years & 33.3 & 36.7 & 30.0 & 40.0 & 33.3 & 17.2 & 31.8 & \\
\hline & $41-50$ years & 6.7 & 16.7 & 36.7 & 23.3 & 0.0 & 13.8 & 16.2 & \\
\hline & $51-60$ years & 10.0 & 6.7 & 10.0 & 6.7 & 30.0 & 20.7 & 14.0 & \\
\hline & $\geq 60$ years & 6.7 & 10.0 & 3.3 & 20.0 & 13.3 & 6.9 & 10.1 & \\
\hline \multirow{4}{*}{$\begin{array}{l}\text { Family } \\
\text { size }\end{array}$} & $1-3$ & 3.3 & 6.7 & 20 & 26.7 & 26.7 & 16.7 & 16.7 & 0.02 \\
\hline & $4-6$ & 30.0 & 23.3 & 36.7 & 16.7 & 36.7 & 30.0 & 28.9 & \\
\hline & $7-9$ & 20.0 & 36.7 & 36.7 & 40.0 & 23.3 & 23.3 & 30.0 & \\
\hline & $>$ & 46.7 & 33.3 & 6.7 & 16.7 & 13.3 & 30.0 & 24.0 & \\
\hline \multirow{5}{*}{$\begin{array}{l}\text { Level of } \\
\text { education }\end{array}$} & Illiterate & 33.3 & 80.0 & 33.3 & 30.0 & 46.7 & 50.0 & 45.6 & 0.001 \\
\hline & Grade 1-4 & 40.0 & 20.0 & 33.3 & 63.3 & 40.0 & 46.7 & 40.6 & \\
\hline & Grade 5-8 & 16.0 & 0.0 & 3.3 & 0.0 & 3.3 & 3.3 & 4.4 & \\
\hline & Grade $9-12$ & 10.0 & 0.0 & 26.7 & 0.0 & 6.7 & 0.0 & 7.2 & \\
\hline & Higher education & 0.0 & 0.0 & 3.3 & 6.7 & 3.3 & 0.0 & 2.2 & \\
\hline \multirow{6}{*}{$\begin{array}{l}\text { Source of } \\
\text { income }\end{array}$} & Livestock and crop farm & 70.0 & 33.3 & 30.0 & 13.3 & 16.7 & 33.3 & 32.8 & 0.001 \\
\hline & $\begin{array}{l}\text { Livestock and day } \\
\text { labourer }\end{array}$ & 6.7 & 26.7 & 20.0 & 16.7 & 10.0 & 10.0 & 15.08 & \\
\hline & Livestock and Trade & 3.3 & 10.0 & 0.0 & 16.7 & 10.0 & 13.3 & 8.9 & \\
\hline & Livestock alone & 6.7 & 16.7 & 36.7 & 43.3 & 56.7 & 20.0 & 30.0 & \\
\hline & Livestock, crop and trade & 13.3 & 0.0 & 0.0 & 10.0 & 0.0 & 13.3 & 6.1 & \\
\hline & $\begin{array}{l}\text { Livestock, crop and day } \\
\text { labour }\end{array}$ & 0.0 & 13.3 & 13.3 & 0.0 & 6.7 & 10.0 & 7.2 & \\
\hline
\end{tabular}

\subsection{Land Holding and Land Use System}

A majority (41.1\%) of respondents in the study area had more than 4 (four) hectares per household table 2. About $11.7 \%$ of households were holding less than 1 hectare. This shows that producers of small ruminants can keep enough animals for the establishment of small scale enterprises if they may be supported and enhanced their entrepreneurship ability. The mean land holding per household in Gelana and Abaya districts was significantly higher $(\mathrm{P}<0.05)$, respectively, than those of other districts, which means these districts are more suitable for the establishment of small scale enterprises engaged in sheep and goat production. 
Table 2: Landholding and land-use system (\%) responded by farmers of the study area

\begin{tabular}{lllllllll}
\hline \multirow{2}{*}{ Description } & & \multicolumn{2}{c}{ Study districts } & & & \\
\cline { 2 - 7 } & & Gedeb & Bule & Amaro & Gelana & Abaya & Dilla Zuria & Total \\
\hline \multirow{2}{*}{ Landholding } & $\leq 1$ hectare & 23.3 & 0.0 & 0.0 & 0.0 & 0.0 & 46.7 & 11.7 \\
& 2-3 hectare & 23.3 & 20.0 & 26.7 & 6.7 & 10.0 & 33.3 & 20.0 \\
& 3-4 hectare & 33.3 & 36.7 & 43.3 & 13.3 & 23.3 & 13.3 & 27.2 \\
& more than 4 & 20.0 & 43.3 & 30.0 & 80.0 & 66.7 & 6.7 & 41.1 \\
\hline Land Use & Livestock\& cash crop & 23.3 & 16.7 & 33.3 & 20.0 & 30.0 & 43.3 & 27.8 \\
& Cereal and livestock & 36.7 & 53.3 & 16.7 & 10.0 & 13.3 & 10.0 & 23.3 \\
& Livestock and pasture & 16.7 & 16.7 & 33.3 & 63.3 & 36.7 & 26.7 & 32.2 \\
& Enset \& livestock & 23.3 & 13.3 & 16.7 & 6.7 & 20.0 & 20.0 & 16.7 \\
\hline
\end{tabular}

An overall of about (32.2\%) of respondents reported that land was used majorly for livestock rearing and natural pasture, while most (27.8\%) of respondents were allocated their land for livestock and cash crop production; especial farmers from Dilla Zuria (43.3\%) were significantly used the land this purpose. Majority of Gelana (63.3\%) and Abaya $(36.7 \%)$ districts' farmers were significantly $(\mathrm{P}<0.05)$ used their land for livestock and pasture, respectively, which implies most farmers of Gelana and Abaya districts' farmers are allocated larger proportion of their land for grazing, while most (53.3\%) farmers of Bule district were significantly used their land for cereal and livestock followed by Gedeb district (36.7\%), which means farmers of Bule and Gedeb districts' farmers are practising crop-livestock farming system.

\subsection{Household Ownership of Different Livestock}

The livestock holding of study districts are summarized in table 3 , shows that there was significant $(P<0.05)$ difference among study districts by most of the livestock species, but chickens were insignificantly $(\mathrm{P}>0.05)$ distributed similarly. Overall average cattle species were the most dominant ( 9.97 heads per household) livestock owned by respondents, followed by Goats ( 7.5 heads/household) and Sheep (5.85 heads per household).

Cattle holding of Abaya district $(17.5 \pm 2.78)$ was significantly higher $(\mathrm{P}<0.05)$ followed by Gelana $(15.57 \pm 2.41)$ and while significantly lower $(\mathrm{P}<0.05)$ in Dilla Zuria $(2.43 \pm 0.56)$. The results show that Dilla Zuria farmers are keeping very limited cattle than other areas. Goats holding was significantly higher $(\mathrm{P}<0.05)$ in Gelana

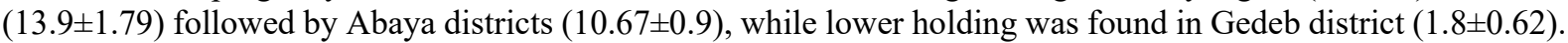
Sheep were significantly dominant in Gedeb (7.9 \pm 0.99$)$ followed by Bule $(7.57 \pm 0.655)$ and Dilla Zaria (7.57 \pm 0.655$)$. Based on these results, Gelana and Abaya districts are found in semi-desert agro-ecology where Goats are commonly produced than Sheep; while Gedeb and Bule districts are slightly found in high altitude why Sheep production is dominated than Goat production.

\subsection{Small Ruminants' Size and Structure}

Table 4, shows that the average Goat flock per household was 7.3. The average number of Goat/household was significantly $(\mathrm{p}<0.05)$ higher in Gelana (13.87) followed by Abaya (10.76) and Amaro (9.3), respectively; while significantly lower in Gedeb (1.76). This is due to landholding capacity, environment and availability of feed for Goat production. The mean number of Does were significantly higher (2.22 \pm 0.14$)$ and castration of Goat was slightly not common $(0.99 \pm 0.13)$ across study districts, which means producers are selling the male Goats before castration and fattening than Does.

The average number of Sheep per household was 5.79heads table 4. The Mean flock size of Sheep/household was significantly higher in Gedeb (7.87) and Bule (7.56), respectively and lower in Gelana (3.83) districts. This result shows that Sheep are preferred high altitude to mid-altitude. Overall Ewes were more dominant $(2.08 \pm 0.13)$ than other sheep structures, which reveals farmers were preferred to sell male sheep than male. Farmers during group discussion informed that matured and fattened Rams were selected by buyers than Ewes and young animals. Table 3: Livestock holding (Mean \pm SE)

\begin{tabular}{|c|c|c|c|c|c|c|c|c|}
\hline \multirow[b]{2}{*}{ Description } & \multicolumn{4}{|c|}{ Study Districts } & \multirow[b]{2}{*}{ Abaya } & \multirow[b]{2}{*}{$\begin{array}{l}\text { Dilla } \\
\text { Zuria }\end{array}$} & \multirow[b]{2}{*}{ Total } & \multirow[b]{2}{*}{$\begin{array}{l}\text { P- } \\
\text { value }\end{array}$} \\
\hline & Gedeb & Bule & Amaro & Gelana & & & & \\
\hline Cattle & $8.03 \pm 0.89^{a}$ & $6.17 \pm 0.75^{\mathrm{ad}}$ & $10.13 \pm 1.24^{\mathrm{ab}}$ & $15.57 \pm 2.41^{\mathrm{b}}$ & $17.5 \pm 2.78^{b c}$ & $2.43 \pm 0.56^{\mathrm{d}}$ & $9.97 \pm 0.77$ & 0.00 \\
\hline Sheep & $7.9 \pm 0.99^{\mathrm{a}}$ & $7.57 \pm 0.65^{\mathrm{ab}}$ & $3.5 \pm 0.98^{\mathrm{bc}}$ & $4.1 \pm 1.16^{\mathrm{bc}}$ & $5.17 \pm 0.85^{\mathrm{b}}$ & $6.8 \pm 0.62^{\mathrm{ab}}$ & $5.85 \pm 0.38$ & 0.01 \\
\hline Goat & $1.8 \pm 0.62^{\mathrm{a}}$ & $2.67 \pm 0.58^{\mathrm{a}}$ & $9.43 \pm 1.05^{b c}$ & $13.9 \pm 1.79^{d}$ & $10.67 \pm 0.9^{b}$ & $6.8 \pm 0.52^{c}$ & $7.5 \pm 0.52$ & 0.00 \\
\hline Chickens & $5.17 \pm 0.71$ & $5.13 \pm 0.6$ & $6.67 \pm 0.75$ & $2.57 \pm 0.71$ & $4.97 \pm 0.88$ & $5.13 \pm 0.62$ & $4.94 \pm 0.3$ & 0.06 \\
\hline
\end{tabular}

Superscripts with different letters across the rows differ significantly $(\mathrm{p}<0.05)$ 
Table 4: Sheep and Goat size and structure (Mean \pm SE)

\begin{tabular}{|c|c|c|c|c|c|c|c|c|}
\hline \multirow{2}{*}{$\begin{array}{l}\text { Small ruminants' size } \\
\text { and flock structure }\end{array}$} & \multicolumn{6}{|c|}{ Study District } & \multirow[b]{2}{*}{ Overall } & \multirow[b]{2}{*}{ Sign. } \\
\hline & Gedeb & Bule & Amaro & Gelana & Abaya & Dilla Zuria & & \\
\hline Goat & 1.76 & 2.63 & 9.37 & 13.87 & 10.76 & 6.78 & 7.53 & \\
\hline Kids $<6$ months & $0.13 \pm 0.10^{\mathrm{a}}$ & $0.27 \pm 0.13^{\mathrm{a}}$ & $1.17 \pm 0.40^{\mathrm{b}}$ & $2.37 \pm 0.44^{\mathrm{c}}$ & $2.43 \pm 0.38^{c}$ & $0.77 \pm 0.24^{\mathrm{ab}}$ & $1.19 \pm 0.14$ & 0.00 \\
\hline Kids 6-12 months & $0.13 \pm 0.07^{\mathrm{a}}$ & $0.53 \pm 0.19^{\mathrm{ac}}$ & $2.00 \pm 0.30^{\mathrm{b}}$ & $2.57 \pm 0.36^{b}$ & $2.17 \pm 0.30^{\mathrm{b}}$ & $0.97 \pm 0.18^{c}$ & $1.39 \pm 0.12$ & 0.00 \\
\hline Does & $0.70 \pm 0.24^{\mathrm{a}}$ & $1.07 \pm 0.23^{\mathrm{a}}$ & $2.73 \pm 0.34^{\mathrm{bc}}$ & $3.43 \pm 0.53^{\mathrm{b}}$ & $3.00 \pm 0.23^{\mathrm{bc}}$ & $2.37 \pm 0.19^{c}$ & $2.22 \pm 0.14$ & 0.00 \\
\hline Bucks & $0.60 \pm 0.24^{\mathrm{a}}$ & $0.63 \pm 0.16^{\mathrm{a}}$ & $2.20 \pm 0.25^{\mathrm{b}}$ & $3.17 \pm 0.45^{\mathrm{c}}$ & $1.83 \pm 0.19^{\mathrm{b}}$ & $1.97 \pm 0.18^{\mathrm{b}}$ & $1.74 \pm 0.13$ & 0.00 \\
\hline Wether /castrates & $0.20 \pm 0.20^{\mathrm{ad}}$ & $0.13 \pm 0.13^{\mathrm{ad}}$ & $1.27 \pm 0.25^{\mathrm{bd}}$ & $2.33 \pm 0.50^{\mathrm{c}}$ & $1.33 \pm 0.33^{\mathrm{bd}}$ & $0.70 \pm 0.23^{\mathrm{d}}$ & $0.99 \pm 0.13$ & 0.00 \\
\hline Sheep & 7.87 & 7.56 & 3.44 & 3.83 & 5.17 & 6.87 & 5.79 & \\
\hline Lambs $<6$ months & $1.43 \pm 0.46$ & $0.83 \pm 0.25$ & $0.37 \pm 0.28$ & $0.57 \pm 0.25$ & $0.73 \pm 0.19$ & $0.60 \pm 0.23$ & $0.76 \pm 0.12$ & 0.17 \\
\hline Lambs 6-12 months & $1.30 \pm 0.39$ & $1.60 \pm 0.22$ & $0.67 \pm 0.22$ & $0.93 \pm 0.32$ & $1.10 \pm 0.22$ & $1.27 \pm 0.23$ & $1.14 \pm 0.11$ & 0.23 \\
\hline Ewes & $2.87 \pm 0.25^{\mathrm{a}}$ & $2.73 \pm 0.30^{\mathrm{a}}$ & $1.20 \pm 0.33^{\mathrm{b}}$ & $1.33 \pm 0.39^{\mathrm{b}}$ & $1.67 \pm 0.26^{b}$ & $2.67 \pm 0.21^{\mathrm{a}}$ & $2.08 \pm 0.13$ & 0.00 \\
\hline Rams & $1.37 \pm 0.18^{\mathrm{ac}}$ & $1.90 \pm 0.24^{\mathrm{a}}$ & $0.60 \pm 0.16^{\mathrm{b}}$ & $0.60 \pm 0.17^{b}$ & $1.17 \pm 0.23^{\mathrm{c}}$ & $1.70 \pm 0.22^{\mathrm{ac}}$ & $1.22 \pm 0.09$ & 0.00 \\
\hline Wither/castrates & $0.90 \pm 0.27$ & $0.50 \pm 0.17$ & $0.60 \pm 0.22$ & $0.40 \pm 0.19$ & $0.50 \pm 0.18$ & $0.63 \pm 0.23$ & $0.59 \pm 0.08$ & 0.65 \\
\hline
\end{tabular}

Superscripts with different letters across the rows differ significantly $(\mathrm{p}<0.05)$

\subsection{The Role of Keeping Small Ruminants}

The current study results revealed that the main purpose of keeping small ruminants was income generation $(0.31)$. This finding is in agreement with that of many scholars' findings (Zelalem and Fletcher, 1991; Tsedeke, 2007; Getahun, 2008,) who reported that the primary reason of small ruminants across Ethiopia is income generation. According to recent studies in the southern part of Ethiopia, Getahun (2008) found out that smallholder farmers in crop-livestock mixed systems kept small ruminants mainly for cash generation.

Moreover, the householders were responded that additional reasons as saving $(0.23)$, home consumption (0.18), risk mitigation (0.17) and Manure (0.11). According to group discussion participants and key informants in the area, coffee is the main cash crop. For most farmers, however, their economic profitability is highly limited by various factors. In most cases, there is a fluctuation of coffee yield; so farmers nowadays keep small ruminants as saving and insurance. Thus, rearing small ruminant with low investment cost is basic for improvement in financial security developing society. Most of the production objectives across Ethiopia agreed with the current finding.

Table5: Purpose of Keeping Sheep and Goats

\begin{tabular}{lllllll}
\hline & \multicolumn{2}{l}{ Rank } & & & \multicolumn{2}{c}{ Index } \\
\cline { 2 - 6 } Description & $\mathbf{1}^{\text {st }}$ & $\mathbf{2}^{\text {nd }}$ & $\mathbf{3}^{\text {rd }}$ & $\mathbf{4}^{\text {th }}$ & $\mathbf{5 t h}^{\text {th }}$ & \\
\hline Income & 141 & 21 & 10 & 6 & 2 & 0.31 \\
Saving & 14 & 89 & 58 & 13 & 6 & 0.23 \\
Home consumption & 13 & 37 & 60 & 26 & 44 & 0.18 \\
Risk mitigation & 12 & 26 & 41 & 76 & 25 & 0.17 \\
Manure & 0 & 7 & 11 & 59 & 103 & 0.11 \\
Total & 180 & 182 & 183 & 184 & 185 & 1 \\
\hline
\end{tabular}

Index $=[(5$ for rank 1$)+(4$ for rank 2$)+(3$ for rank 3$)+(2$ for rank4 $)+(1$ for rank5 $)]$ divided by the sum of all weighted value of mentioned purposes by respondents.

\subsection{Small Ruminants' Production System}

\subsubsection{Local Available Feed Resources and Feeding System}

Current study results revealed that locally available feed resources are abundant across study areas. Key informants are informed that area is suitable and conducive for small ruminants' production; because of locally available feed resources like natural grasses, browsing herb, multipurpose trees, roadside and aftermath grazing, and crop residues are found dominantly across districts of the study area. This disagreed with findings of (Endeshaw, 2007; Tsedeke, 2007; Getahun, 2008) stated that feed shortage is a major constraint for small ruminants production in the southern part of the country, although the degree of shortage varies within farming systems/agro-ecologies.

Farmers are mentioned a lot of mainly local natural pasture (natural grasses and browses), Grass species like Cynodon dactylon (Sardo/edo), Cenchrus ciliaris (Matagudessa), Pennisetum mezianum (Bamboo grass/Ogondo), Digitaria neghellensis (Elmogori), Heteropogon contortus (Saricha), Eragrostis sp, Chloris roxburghiana (horse tail) are found. Cynodon dactylon (Sardo/edo) is preferred as best feed in Gedeb and Bule followed by Pennisetum mezianum (Bamboo grass/Ogondo). Digitaria neghellensis (Elmogori) and Cenchrus ciliaris (Matagudessa) are valued as best feed at Amaro, Gelana and slightly in Abaya and Dilla Zura districts.

There are browses (shrubs, tree leaves and pods) mainly found in Amaro, Gelana and Abaya districts. Browses species like Acacia tortilis (Tadacha/Dadacha), Acacia seyal (Wachu), Acacia mellifera (Sapensa), Acacia etbaica (Alkabesa), Acacia nilotica (Burkuke), Acacia brevispica (Hamaressa), Acacia bussei (Alo), Balanites aegyptiaca (Badena), Commiphora species and others play a very important role as sources of feed of small ruminants. All respondents are ranked these all browses as best feed and highly palatable by small ruminants. Yeshitila (2007) 
also reported the utilization of indigenous browses as feed resources in Alaba district of SNNPR

About $28.3 \%$ of respondents were using natural pasture, followed by grazing and browsing $(21.1 \%)$, while some $(15 \%)$ of respondents were utilizing aftermath grazing (Table 6). Households from Abaya (53.3\%) and Gelana $(40 \%)$ were significantly $(\mathrm{P}<0.05)$ utilizing communal natural pasture grazing land. The use of crop residue was common (33.3\%) in Gedeb followed by Bule $(26.7 \%)$ even if farmers in the study area have a limited practice of feed conservation.

Table 6: Major local feed available and feeding system of small ruminants (\%)

\begin{tabular}{|c|c|c|c|c|c|c|c|c|c|}
\hline \multirow{2}{*}{\multicolumn{2}{|c|}{ Major feed availability }} & \multirow{2}{*}{\multicolumn{6}{|c|}{ Study District (\%) }} & \multirow[t]{2}{*}{ Total } & \multirow[t]{2}{*}{ Sig. } \\
\hline & & & & & & & & & \\
\hline Not 1 Dosto & & \multirow{2}{*}{\begin{tabular}{|l|} 
Gedeb \\
16.7
\end{tabular}} & \multirow{2}{*}{$\begin{array}{c}\text { Bule } \\
16.7\end{array}$} & \multirow{2}{*}{$\begin{array}{l}\text { Amaro } \\
33.3\end{array}$} & \multirow{2}{*}{$\begin{array}{l}\text { Gelana } \\
40.0\end{array}$} & \multirow{2}{*}{$\begin{array}{l}\text { Abaya } \\
53.3\end{array}$} & \multirow{2}{*}{$\begin{array}{l}\begin{array}{l}\text { Dilla } \\
\text { Zuria }\end{array} \\
10.0\end{array}$} & & \\
\hline Natural Pasture & & & & & & & & 28.3 & 0.00 \\
\hline Roadside grazing & & 10.0 & 26.7 & 13.3 & 13.3 & 0.0 & 33.3 & 16.1 & \\
\hline Grazing and Brows & & 13.3 & 13.3 & 20.0 & 23.3 & 30.0 & 26.7 & 21.1 & \\
\hline Aftermath grazing & & 26.7 & 16.7 & 13.3 & 6.7 & 10.0 & 16.7 & 15. & \\
\hline Crop residue & & 33.3 & 26.7 & 20.0 & 16.7 & 6.7 & 13.3 & 19.4 & \\
\hline \multirow[t]{4}{*}{ Non- conventional } & Chat leftover & 26.7 & 33.3 & 16.7 & 23.3 & 26.7 & 13.3 & 23.3 & 0.36 \\
\hline & Fruit leftover & 23.3 & 13.3 & 23.3 & 30.0 & 16.7 & 33.3 & 23.3 & \\
\hline & Coffee pulp & 20.0 & 6.7 & 30.0 & 20.0 & 33.3 & 20.0 & 21.7 & \\
\hline & Enset leaves & 30.0 & 46.7 & 30.0 & 26.7 & 23.3 & 33.3 & 31.7 & \\
\hline \multirow{2}{*}{$\begin{array}{l}\text { Do you give a } \\
\text { supplement? }\end{array}$} & Yes & 80.0 & 60.0 & 70.0 & 66.7 & 53.3 & 76.7 & 67.8 & 0.22 \\
\hline & No & 20.0 & 40.0 & 30.0 & 33.3 & 46.7 & 23.3 & 32.2 & \\
\hline \multirow[t]{4}{*}{$\begin{array}{ll}\text { Type } & \text { of } \\
\text { supplements }\end{array}$} & $\begin{array}{l}\text { Industrial by- } \\
\text { product }\end{array}$ & 36.7 & 26.7 & 30.0 & 26.7 & 10.0 & 33.3 & 27.2 & 0.00 \\
\hline & $\begin{array}{l}\text { Local mineral } \\
\text { soil }\end{array}$ & 43.3 & 33.3 & 40.0 & 40.0 & 43.3 & 6.7 & 34.4 & \\
\hline & Mixed ration & 0.0 & 0.0 & 0.0 & 0.0 & 0.0 & 13.3 & 2.2 & \\
\hline & Salt & 0.0 & 0.0 & 0.0 & 0.0 & 0.0 & 23.3 & 3.9 & \\
\hline \multirow{3}{*}{$\begin{array}{l}\text { Period } \\
\text { supplement }\end{array}$} & Dry period & 30.0 & 36.7 & 46.7 & 36.7 & 40.0 & 23.3 & 35.6 & 0.01 \\
\hline & Wet period & 13.3 & 0.0 & 0.0 & 0.0 & 0.0 & 16.7 & 5.0 & \\
\hline & Every when & 36.7 & 23.3 & 23.3 & 30.0 & 13.3 & 36.7 & 27.2 & \\
\hline
\end{tabular}

The majority (31.7\%) of households were feeding enset leaves, followed by Chat leftover (23.3\%) and fruit leftover $(23.3 \%)$ as non-conventional feed. Enset leaves feeding was significantly $(\mathrm{P}<0.05)$ common in Bule (46.7\%) and Dilla Zuria (33.3\%). All key informative during group discussion was stated that non-conventional feed resources are commonly given to small ruminants. Chat leftover, coffee pulp; fruit parts, enset and house leftover are known non-conventional feeds across the study area.

Almost all $(67.8 \%)$ of respondents were responded that supplementation is not common, which implies feed management is very poor and most $(32.3 \%)$ of farmers were supplemented additional feeds their animals. The majority (34.4\%) of respondents were supplementing local mineral soil called "Bole" obtained from Lake Abaya, followed by supplementing industrial by-products $(27.1 \%)$. The supplementation was higher (35.6\%) during the dry season and most $(27.2 \%)$ of respondents were giving supplement feed everywhen; mineral supplement like "Bole" was available with cheap price nearby production areas. The availability and quality of feeds are not favourable and uniform in nutrient quality all year round. As a result, for the animal that is not supplemented the gains made in the wet season is totally or partially lost in the dry season (Alemayehu, 2003).

There were no farmers respondents that conserved feed resource inform of silage, hay or any other feed preservation strategies at the area. The farmers hadn't obtained any sorts of training on improved feed conservation and preservation mechanisms.

\subsubsection{Housing Management}

Almost all small ruminant producers provided night shelter, even if the type and place of sheltering vary. The majority $(37.8 \%)$ of respondents provided night shelter to their small ruminants in adjacent to the family house, separate room (27.8\%) and living with the family house (24.4\%) with some sort of partition table 7 . About $44.4 \%$ of respondents housed sheep and goat together, while about $55.6 \%$ of respondents housed sheep and goats separately. According to a group discussion with participants, the qualities and standards of houses were very poor; not well cleaned, in most areas the shelters are roofless, and thus, poor housing management can directly or indirectly affect the production and productivity of small ruminants, which observed during the direct survey.

The majority $(49.4 \%)$ of respondent stated that they provide shelter to protect from predators, followed by protecting unfavourable condition $(28.9 \%)$. The current results are similar with many other findings ((Endeshew, 2007; Tsedeke, 2007; Belete, 2009), who stated that night time housing of small ruminants through Ethiopia is to protect from predators, unfavourable condition and theft, and housed in adjacent to the family house, within the 
family house and in a separate house.

Table 7: Percent of household responded on housing type, means of confining and reasons for sheltering Small ruminants during night

\begin{tabular}{|c|c|c|c|c|c|c|c|c|c|}
\hline \multirow{2}{*}{\multicolumn{2}{|c|}{ Description }} & \multirow{2}{*}{\multicolumn{6}{|c|}{ Study Districts }} & \multirow{3}{*}{ Total } & \multirow{3}{*}{$\begin{array}{l}P \text { - } \\
\text { value }\end{array}$} \\
\hline & & & & & & & & & \\
\hline \multirow{5}{*}{$\begin{array}{l}\text { Housing } \\
\text { system }\end{array}$} & & & & & & & & & \\
\hline & Living with family house & 26.7 & 30.0 & 20.0 & 23.3 & 10.0 & 36.7 & 24.4 & \multirow[t]{4}{*}{0.00} \\
\hline & $\begin{array}{l}\text { Partition adjacent to the } \\
\text { family house }\end{array}$ & 40.0 & 36.7 & 53.3 & 30.0 & 30.0 & 36.7 & 37.8 & \\
\hline & Separate room & 33.3 & 33.3 & 26.7 & 16.7 & 30.0 & 26.7 & 27.8 & \\
\hline & Separate shed/fence & 0.0 & 0.0 & 0.0 & 30.0 & 30.0 & 0.0 & 10.0 & \\
\hline \multirow{3}{*}{$\begin{array}{l}\text { How to } \\
\text { confine }\end{array}$} & Sheep alone & 46.7 & 66.7 & 0.0 & 13.3 & 26.7 & 26.7 & 30.0 & \multirow[t]{3}{*}{0.00} \\
\hline & Goats alone & 3.3 & 0.0 & 60.0 & 33.3 & 33.3 & 23.3 & 25.6 & \\
\hline & Sheep and Goats together & 50.0 & 33.3 & 40.0 & 53.3 & 40.0 & 50.0 & 44.4 & \\
\hline \multirow{4}{*}{$\begin{array}{l}\text { Why } \\
\text { provide } \\
\text { shelter }\end{array}$} & $\begin{array}{l}\text { To protect from the } \\
\text { unfavourable condition }\end{array}$ & 20.0 & 36.7 & 30.0 & 23.3 & 23.3 & 40.0 & 28.9 & \multirow[t]{4}{*}{0.00} \\
\hline & To protect from predators & 66.7 & 63.3 & 53.3 & 33.3 & 36.7 & 43.3 & 49.4 & \\
\hline & $\begin{array}{l}\text { To provide convenient } \\
\text { climatic condition }\end{array}$ & 10.0 & 0.0 & 16.7 & 0.0 & 13.3 & 0.0 & 6.7 & \\
\hline & To protect from theft & 3.3 & 0.0 & 0.0 & 43.3 & 26.7 & 16.7 & 15.0 & \\
\hline
\end{tabular}

\subsubsection{Major Constraints of Small Ruminants Production}

The major constraints in small ruminants' production in the area are summarized in Table 8: Majority (21.7\%) respondents responded that lack of extension and credit supports were ranked the first problem that affects the production of small ruminants in small scale enterprise level. Lack of extension and credit supports were significantly higher in Bule district (33.3\%) followed by Gelana (26.7\%) and Dilla Zuria (26.7\%), respectively. This shows that extension and credit services which have a great role in the development of small scale enterprises are not given by governmental and NGOs.

Table 8: Major problems reported by respondents of small ruminant producers $(\%)$

\begin{tabular}{lllllllll}
\hline Description & \multicolumn{2}{c}{ Districts } & & & & & & P- \\
& Gedeb & Bule & Amaro & Gelana & Abaya & $\begin{array}{l}\text { Dilla } \\
\text { Zuria }\end{array}$ & Total & $\begin{array}{l}\text { value } \\
\text { Diseases and parasites }\end{array}$ \\
\hline & 13.3 & 10.0 & 33.3 & 30.0 & 16.7 & 0.0 & 17.2 & 0.00 \\
Feed and grazing land shortage & 16.7 & 23.3 & 6.7 & 0.0 & 13.3 & 30 & 15.0 & \\
Genetic improvement problems & 3.3 & 0.0 & 0.0 & 0.0 & 0.0 & 0.0 & 0.6 & \\
Predators & 30.0 & 20.0 & 16.7 & 0.0 & 0.0 & 0.0 & 11.1 & \\
Market problems & 6.7 & 13.3 & 23.3 & 23.3 & 16.7 & 20.0 & 17.2 & \\
Lack of technologies & 13.3 & 0.0 & 10.0 & 20.0 & 36.7 & 23.3 & 17.2 & \\
Lack of extension and credit & 16.7 & 33.3 & 10.0 & 26.7 & 16.7 & 26.7 & 21.7 &
\end{tabular}

support

Diseases and Parasites, market problems, and Lack of technologies were equally (17.2\%) reported by respondents. Moreover, all key informants stated health problem, poor management, lack of credit; marketing infrastructure and seasonal feed scarcity as major constraints in producing small ruminants. During group discussion farmers from Bule district were informed that the government is trying to improve the sheep breed by giving them; "Bonga breed Ram" sheep.

\subsubsection{Potentials of Small Ruminants Production}

Producing sheep and Goat has more opportunities than keeping other livestock. The current study results revealed that most of the producers of small ruminants were benefited from increased demand $(33.3 \%)$ of small ruminant animals and their products in the domestic and export market (table 10). This is due to expanding emerging export market at the national level, which agreed with the report of Legese et al.; (2008) stated that Ethiopian meat is competing with meat from New Zealand, Brazil, India and Pakistan in the Gulf markets. 
Table 10: Major opportunities for producing small ruminant responded by households (\%)

\begin{tabular}{|c|c|c|c|c|c|c|c|}
\hline \multirow[t]{2}{*}{ Description } & \multicolumn{6}{|c|}{ Districts } & \multirow[b]{2}{*}{ Total } \\
\hline & Gedeb & Bule & Amaro & Gelana & Abaya & $\begin{array}{l}\text { Dilla } \\
\text { Zuria }\end{array}$ & \\
\hline Locally available feed & 26.7 & 10.0 & 13.3 & 13.3 & 30.0 & 26.7 & 20.0 \\
\hline $\begin{array}{l}\text { Expanding emerging internal } \\
\text { demand and export market }\end{array}$ & 30.0 & 33.3 & 46.7 & 33.3 & 16.7 & 40.0 & 33.3 \\
\hline $\begin{array}{l}\text { Animal breed and reproductive } \\
\text { performance }\end{array}$ & 23.3 & 6.7 & 13.3 & 13.3 & 20.0 & 10.0 & 14.4 \\
\hline Conducive Environment & 3.3 & 20.0 & 6.7 & 13.3 & 10.0 & 10.0 & 10.6 \\
\hline Low investment cost & 6.7 & 13.3 & 10.0 & 16.7 & 13.3 & 3.3 & 10.6 \\
\hline Easy to manage & 10.0 & 16.7 & 10.0 & 10.0 & 10.0 & 10.0 & 11.1 \\
\hline
\end{tabular}

The producers also mentioned potentially available feed (20\%), best breed and reproductive performance of animal $(14.4 \%)$, easy to manage $(11.1 \%)$, conducive environment $(10.6 \%)$ and low investment cost $(10.6 \%)$ as best opportunities to produce small ruminants in study areas.

\subsection{Small Scale Enterprises and entrepreneurship engaged in small Ruminants' Production}

All of the householders $(100 \%)$ were responded that there is neither a small scale enterprise nor smallholder engaged in small ruminants' production. Across the study areas, the Governmental and/or non-governmental organizations were not concerned about awareness creation in generating information and knowledge on enterprise and entrepreneurship, extension services and technology inputs. However, according to Legesse et al., (2008) different NGOs and projects tried to strengthen the small scale sheep and goat enterprises and link them to different market chains, however, none of them is profitable because they could not compete with individual producer and trader.

\section{CONCLUSIONS AND RECOMMENDATIONS}

\subsection{Conclusions}

In the study area, most of the farmers were illiterate. The overall landholding is largely used for livestock, pasture, cash crop, cereals and enset production. Sheep are dominant in Gedeb and Bule, and Goats are dominant in Gelana, Abaya and Amaro, respectively, while both sheep and Goats kept equally in Dilla Zuria. Across study districts, small ruminants are kept primarily for income generation. In the area, production of a small ruminant is well known, easy and productive; because the environment is conducive, locally available feed resources are abundant, animals' reproductive performance is high and demand for small ruminant is increasing. Lack of extension and credit support, diseases and parasites, market problem and lack of production technology are major factors. There is no small scale enterprise engaged in sheep and goat production, this is due to a lack of entrepreneurship ability and lack of awareness to make small scale enterprise or cooperatives.

\subsection{Recommendations}

Based on the above conclusions the following recommendations are made:

$>$ Support should be given to producers by governmental and non- governmental organizations in all management practices of small ruminants.

$>$ Training should be given on awareness creation, skill development, and knowledge sharing

$>$ Market and production chain analysis must be done

$>$ Small scale enterprises must be established

\section{REFERENCES}

Alemayehu M. (2003). Country pasture/forage resources profiles: Ethiopia. FAO (Food and Agriculture Organization of the United Nations), Rome, Italy.

Behnke, R. and Fitaweke, M. (2011). The contribution of livestock to the Ethiopian economy-Part II. IGAD LPI Working Paper No. 02-11. Djibouti: IGAD Livestock Policy Initiative.

Belay, D., K. Yisehak and G.P. Janssens, (2012). Survey of major diseases affecting dairy cattle in Jimma town, Oromia, Ethiopia. Global Veterinaria8(1): 62-66.

Belete, S. (2009). Production and marketing systems of small ruminants in Goma District of Jimma Zone, western Ethiopia. MScthesis. Awassa, Ethiopia: Hawassa University

Central Statistical Agency (2007). Agricultural sample survey 2006/07.Volume II.Report on livestock and livestock characteristics. Statistical Bulletin 388. Addis Ababa, Ethiopia: CSA

Central Statistical Agency (2013). Agricultural sample survey, 2012/2013 (2005 EC). Report on livestock and livestock characteristics. Statistical Bulletin 570. Addis Ababa,Ethiopia: CSA.

Dhaba Urgessa, Belay Duguma, Solomon Demeke and Taye Tolamariam (2012). Sheep and Goat Production 
Systems in Ilu Abba Bora Zone of Oromia Regional State, Ethiopia: Feeding and Management Strategies. Global Veterinaria 9 (4): 421-429

Ethiopian Customs and Revenue Authority (2012). Raw data on the type, volume, value and destination of export items from Ethiopia. Addis Ababa, Ethiopia: ECRC.

Endeshaw A. (2007). Assessment on production system and marketing of goats at Dale district (Sidama Zone). MSc Thesis. Hawassa University, Awassa, Ethiopia

Getahun L. (2008). Productive and Economic performance of Small Ruminant production in production system of the Highlands of Ethiopia. Ph.D.dissertation. University of Hohenheim, Stuttgart-Hoheinheim, Germany.

Legese, G., Teklewold, H., Alemu, D. and Negassa, A. (2008). Live animal and meat export value chains for selected areas in Ethiopia: constraints and opportunities for enhancing meat exports. ILRI Improving Market Opportunities Discussion Paper 12. Nairobi, Kenya: ILRI.

National Bank of Ethiopia (2011). Annual report 2009/2010. Addis Ababa, Ethiopia: NBE.

Solomon, G.,Azage,T. Berhanu, G. and Hoekstra, D. (2010). Sheep and goat production and marketing systems in Ethiopia: Characteristics and strategies for improvement. Improving Productivity and Market Success (IPMS) Working Paper No. 23. Addis Ababa, Ethiopia: ILRI.

Software Package for Social Sciences for Window (2013)

Tsedeke K. (2007). Production and marketing of sheep and goats in Alaba, SNNPR. Msc thesis.Hawassa University. Awassa, Ethiopia

Yeshitila A. (2007). Efficiency of livestock feed resources utilization and forage development in Alaba woreda, southern Ethiopia. MSc Thesis. Haramaya University, Haramaya, Ethiopia.

Zelalem, A. and Fletcher I. (1991). Small ruminant productivity in the central Ethiopian mixed farming systems. Proceedings of the 4th NLIC, 13-15. November 1991. Addis Ababa, Ethiopia, pp: 141-147 